\title{
Detection of Pseudomonas aeruginosa in Clinical Samples Using PCR Targeting ETA and gyrB Genes
}

\author{
Khulod Ibraheem Hassan ${ }^{1^{*}}$ \\ Saman Rafeeq Abdullah ${ }^{2}$
}

Received 20/5/2018, Accepted 17/7/2018, Published 9/12/2018

This work is licensed under a Creative Commons Attribution 4.0 International License.

\begin{abstract}
:
Pseudomonas aeruginosa has variety of virulence factors that contribute to its pathogenicity. Therefore, rapid detection with high accuracy and specificity is very important in the control of this pathogenic bacterium. To evaluate the accuracy and specificity of Polymerase Chain Reaction (PCR) assay, $E T A$ and $g y r B$ genes were targeted to detect pathogenic strains of $P$. aeruginosa. Seventy swab samples were taken from patients with infected wounds and burns in two hospitals in Erbil and Koya cities in Iraq. The isolates were traditionally identified using phenotypic methods, and DNA was extracted from the positive samples, to apply PCR using the species specific primers targeting ETA, the gene encoding for exotoxin A, and $g y r B$ gene. The results of this study indicate that $100 \%$ of $P$. aeruginosa isolates harbored the gyrB gene, whereas $74 \%$ of these isolates harbored ETA gene. However, the specificity of PCR for detection of $P$. aeruginosa based on the both genes was $100 \%$, since no amplified product obtained using DNA extracted from other bacterial species. Hence by considering the importance of rapid detection of this bacterium due to the presence of problems in biochemical methods, PCR targeting multiple virulence genes is suggested in identification of pathogenic strains of $P$. aeruginosa isolated from some infections which should speed diagnosis of an antimicrobial therapy.
\end{abstract}

Key words: Pseudomonas aeruginosa, identification, PCR, ETA gene, gyrB Gene.

\section{Introduction:}

Pseudomonas aeruginosa is an environmentally ubiquitous Gram-negative bacterium which is a leading nosocomial pathogen causing various infectious syndromes (1). Clinically, this microorganism plays a critical role in the survival rates of affected patient; hence it is important to detect it quickly and accurately. In general, detection of $P$. aeruginosa is done by standard traditional culture such as morphologic and biochemical tests (2). However these tests are lengthy and unreliable and because of the seriousness of the infection, there is a need for a rapid and sensitive technique for early detection of pathogenic P.aeruginosa DNA-based techniques, such as polymerase chain reaction (PCR) are shown to have those characters for the identification of pathogenic bacteria in terms of accuracy, specificity and reliability (3). Many of these PCR methods have been applied for identification of $P$. aeruginosa $(4,5)$.

\footnotetext{
Department of Food Science\& Human Nutrition, College of Agricultural Science, Sulamani University, Sulamani, Iraq.

${ }^{2}$ Koya Technical Institutes, Erbil Polytechnic University, Koya, Iraq

*Correspondence: khlood.hassan@univsul.edu.iq
}

A variety of virulence factors contribute to the pathogenicity of P.aeruginosa and are targeted by PCR for its detection such as oprL gene and exoS gene (6), gyrB gene (2,7), ecfX genes (8), Quorum sensing gene (9), gene encoded to phospholipase $(p l c H)$, rhamnolipid $\mathrm{AB}(\operatorname{rhl} \mathrm{AB})$, alkaline protease (aprA) and elastase (lasB) (10) beside exotoxin A (ETA gene) $(11,12)$. ETA gene is species specific and conserved for P.aeruginosa species and is not present in other species of Psuedomonas genus. The gene encoding exotoxin A has been sequenced, characterized and is known to contribute to $P$. aeruginosa pathogenesis, since strains of this species of bacteria are deleted for this gene are less damaging than parental strains (13). The main problem of PCR detection methods of $P$. aeruginosa is that they target only one gene which is inadequate for comprehensive and reliable diagnosis $(7,14)$. Because $P$. aeruginosa strains demonstrate high genotypic diversity (15), and many studies have confirmed the absence of one or more of the virulence genes in some strains (16), this study aimed to detect pathogenic strains of $P$. aeruginosa by targeting ETA gene and another gene called $g y r B$ that encodes the subunit B protein of DNA gyrase $(7,8)$. 


\section{Materials and Methods: \\ Bacterial isolation:}

Between June and October 2015, 70 swab samples were taken from infected wounds and burns from patients attending the hospitals in Erbil and Koya cities in the Kurdistan region of Iraq. Brain Heart Infusion Broth was used to enrich the bacteria, and this was cultured on MacConkey agar plates and incubated at $37^{\circ} \mathrm{C}$ overnight to observe colony morphology. The observed colonies were inoculated on the selective medium (cetrimide agar) and processed further for biochemical tests according to MacFaddin (17) which include: Growth at $42^{\circ} \mathrm{C}$ in trypticase soya agar, Indole production test, Vogesproskauer (VP), Methyl red test, urease activity, Oxidase test, Citrate utilization test, and catalase test.

\section{DNA Extraction:}

Genomic DNA was prepared according to Oliveira et al. (18) as follows: From a single colony $10 \mathrm{ml}$ cultures were prepared in broth media for 12 hours, then centrifuged for $5 \mathrm{~min}$ at $6000 \mathrm{rpm}$ to pellet the cells, The pellets were resuspend in TE buffer $(\mathrm{PH}$ 8) and $30 \mathrm{mg} / \mathrm{ml}$ lysozyme and incubated for 2 hours at $37^{\circ} \mathrm{C}$. After that, TE buffer $(\mathrm{pH} 8)$ containing Proteinase K $(1 \mathrm{mg} / \mathrm{ml})$ was added for 1 hour for denaturation of cell protein, and $10 \mu \mathrm{l}$ of 20\% Sodium Dodocyl Sulfate (SDS) was added and incubated for $1 \mathrm{~h}$ at $37^{\circ} \mathrm{C}$. One equal volume of phenol /chloroform/isoamyl alcohol (24/24/1) was added and put in to a shaker for 30 minutes, and was centrifuged for $5 \mathrm{~min}$ at $6000 \mathrm{rpm}$. The supernatant was transferred into a clean micro tube and then ammonium acetate was added by $10 \%$ of the volume with one equal volume of cold isopropanol to precipitate the genomic DNA. The precipitated DNA was transferred into another micro tube and washed with $200 \mu \mathrm{l}$ of $(70 \%)$ ethanol. Finally, the washed DNA was dissolved in TE buffer and stored at $-20^{\circ} \mathrm{C}$ until use.

\section{Application of Polymerase Chain Reaction:}

Two sets of primers were used in the application of PCR. The first one was forward primer 5' GACAAC GCCCTCAGCATCACCAGC3'and the second was reverse primer 5'CGCTGGCCCATTCGCTCCAGCGCT 3',which targeted exotoxin A (ETA) gene, which amplified a $222 \mathrm{bp}$ snippet. The second set of primes was a forward primer

5'AAGTACGAAGGCGGTCTGAA3' and reverse primer 5'GTTGTTGGTGAAGCAGAGCA3' which was targeting gyrB gene which amplifies a 367bp sequence, with both genes were specific for $P$. aeruginosa. The reagents required for PCR reaction include $25 \mu 1$ reaction mixture, with $2 \mathrm{U}$ of Taq
DNA polymerase, $2.5 \mu 1$ of $10 \mathrm{x}$ PCR buffer $(10 \mathrm{mM}$ of Tris- $\mathrm{HCl}$ (pH8.5), $30 \mathrm{mM}$ of $\mathrm{KCl}, 1.5 \mathrm{mM}$ of $\mathrm{MgCl}_{2}$, and $0.4 \mathrm{mM}$ of each dNTPs with $50 \mathrm{ng}$ template DNA beside $10 \mathrm{pmol}$ of each primer $(0.5 \mu \mathrm{M})$. The amplification program was run as follow: One cycle at $95^{\circ} \mathrm{C}$ for $2 \mathrm{~min}, 30$ cycles of $92^{\circ} \mathrm{C}$ for $60 \mathrm{~s}, 59^{\circ} \mathrm{C}$ for ETA gene and $55^{\circ} \mathrm{C}$ for gyrB gene as annealing temperature and $72^{\circ} \mathrm{C}$ for 1 $\mathrm{min}$, and finally One cycle at $72^{\circ} \mathrm{C}$ for $8 \mathrm{~min}$. The amplified product was run on $1.2 \%$ agarose gel electrophoresis for $90 \mathrm{~min}$ at 75 Volts, stained with ethidium bromide and visualized by a U.V. transilluminator.

\section{Results and Discussion: \\ Identification of $P$. aeruginosa using phenotypic methods.}

Out of 70 samples collected from patients with infected wounds and burns, 24 (34\%) of the isolates were successfully diagnosed as $P$. aeruginosa, using phenotypic methods. This reflects that $P$. aeruginosa is widely exists in hospital environments such as air and distribution systems (19). Moreover, P. aeruginosa has acquired many antibiotic resistance genes and therefore dominant compared to other kinds of bacteria. As this bacteria is introduced into areas when membranes and skin are disrupted by direct tissue damage, this makes $P$. aeruginosa prevalent in wound and burn trauma. The results of phenotypic tests include formation of large, pale, translucent and mucoid colonies on MacConkey agar plates, and formation of a greenish blue color on nutrient agar (due to production of pyocanin and fluorescin pigments).The identification of the isolates was confirmed by API 20E system and biochemical assays results $(20,21)$. Despite the successful use of traditional methods for identification of $P$. aeruginosa, it is often lengthy and still needs validation. Because Pseudomonas species are phenotypically very unstable and therefore, detection of this bacteria at the molecular level is very important especially for its pathogenic strains.

\section{PCR Analysis}

Recently, it his become difficult to cure infections caused by $P$. aeruginosa due to its acquisition many new antibiotic resistance genes that allow it to survive and distribute easily and convert to chronic colonization (22), Therefor early diagnosis and control of this pathogen have become vital for positive patient outcomes. Many researchers attempted to develop DNA -based techniques especially PCR for detection of $P$. aeruginosa due to its ease and accuracy, However, a definitive methodology still lacking. Two pairs of primers specific to $P$. aeruginosa genes were used 
in this study. The benefit of using more than one targeting gene for identification of one organism is to provide more confirmation and confidence in the identity of the organism, and to reduce the potential of false negative results caused by sequence variation in the primers (23). The first pair was targeting exotoxin A (ETA) gene as many studies targeted the same gene for identification of $P$. aeruginosa $(24,25)$. Amplified products of the predicted size of $222 \mathrm{bp}$ were obtained using the DNA extracted from $74 \%$ of $P$. aeruginos isolates (Fig1). These results were in accordance with that recorded by Naiem (26) who detect this gene in $66 \%$ of the strains that were collected from human clinical infection samples from Al-Diwanyia (Iraq) hospital. This ratio increased to $73 \%$ in other studies conducted on samples collected in Baghdad (27). The ratio increased to $75 \%$ in a study conducted on samples collected from Kirkuk Hospital (28). Exotoxin A is produced by the majority of pathogenic $P$. aeruginosa isolates and can inhibit protein biosynthesis of the host at the level of stopping polypeptide chain elongation factor 2 (29). The absence of ETA gene from some strains is due to the mutation of that gene. By applying PCR targeting of another virulence gene ( $g y r B$ gene), the results showed amplified fragment with $367 \mathrm{bp}$ in $100 \%$ of the isolates (Fig 2), the same results obtained with other studies $(25,30)$, indicating the presence of this gene in the conserved region of the genome of this bacteria, The difference in percentage of virulence genes is due to several reasons including nature of place, and type of prevalence strains (31). Since the specificity of PCR primers is very important criterion needed for detection of any bacteria, it was investigated for detection of $P$. aeruginosa based on the two genes used in this study, It was 100\% accuracy, this result is agreed with that reported by other studies (32), Since no amplified product obtained using the DNA that extracted from other various bacterial species including Salmonella typhymerium, Staphylouocus aureus, Shigella dysenteriae and Escherichia coli. The present study is first of its kind in Erbil/Iraq to detect the presence and distribution of two virulence genes tox $A$ and gyrB gene across the genome of $P$. aeruginosa isolates by PCR. Moreover, this technique was a confidant assay and specific for identification of this bacterium in short time with low cost.

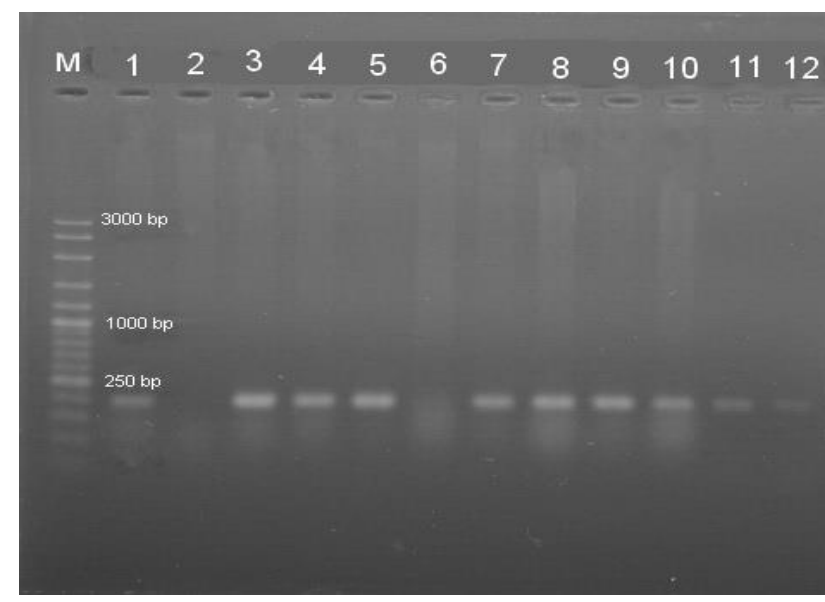

Figure 1. PCR amplification of ETA gene of $P$. aeruginosa, M: DNA ladder, lanes $1,2,3, \ldots . .12$ represent amplified product $(222 \mathrm{bp})$ of $P$. aeruginosa isolates.

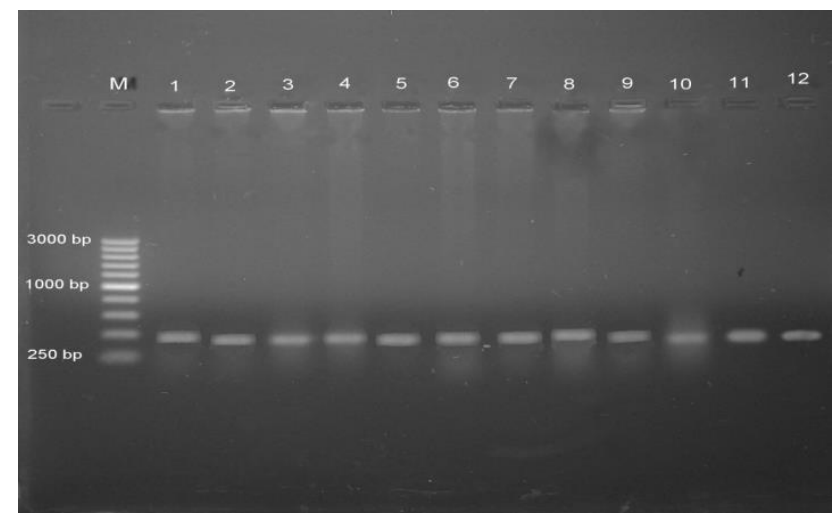

Figure 2. PCR amplification of gyrB gene of $P$. aeruginosa, M: DNA ladder, lanes 1, 2, 3,...12 represent amplified product $(367 \mathrm{bp})$ of $\boldsymbol{P}$. aeruginosa isolates.

\section{Conclusion:}

The results indicate that $100 \%$ of $P$. aeruginosa isolates from burn and wound infections harbored $g y r B$ gene, whereas $74 \%$ of these isolate had ETA gene. Considering the importance of rapid and early detection of pathogenic strains of any bacteria due to the time and resources required for biochemical methods, PCR targeting multiple virulence genes (ETA and $g y r B)$ is suggested for the identification of pathogenic strains of $P$. aeruginosa. This assay can be used for screening of some infections for effective antimicrobial therapy.

\section{Conflicts of Interest: None.}

\section{References}

1. Buhl M., Peter S, Willmann M. Prevalence and risk factors associated with colonization and infection of extensively drug-resistant Pseudomonas aeruginosa: A systematic review. Expert Rev. Anti-Infect. Ther. 2015;13:1159-1170. 
2. Qin X, Emerson J, Stapp J, Stapp L, Abe P, Burns JL. Use of real-time PCR with multiple targets to identify Pseudomonas aeruginosa and other non fermenting Gram-negative bacilli from patients with cystic fibrosis. J Clin Microbiol.2003; 41:4312-4317.

3. Procop GW.Molecular diagnostics for the detection and characterization of microbial pathogens. Clin Infect Dis.2007; 1:99-111.

4. Faraji F, Mahzounieh M, Ebrahimi A1, Fallah F , Teymournejad O, Lajevardi B . Molecular detection of virulence genes in Pseudomonas aeruginosa isolated from children with Cystic Fibrosis and burn wounds in Iran. Microb Pathog.2016, Jul 99:1-4.

5. McCarthy KL,Wailan AM ,Jennison AV,Kidd TJ ,Paterson DL. P. aeruginosa blood stream infection isolates: A "full house" of virulence genes in isolates associated with rapid patient death and patient survival. Microb Pathog. 2018, June. 119 : 81-85.

6.Chen G, Feng Y,Ying W, Yaling L, Jinyong Z ,Hao Z et.al. Vaccination with a recombinant OprL fragment induces a Th17 response and confers serotypeindependent protection against Pseudomonas aeruginosa infection in mice. Clin. Immunol. 2017, October, 183: 354-363.

7. Mehrdad HA, Moghaddama M, Mohammad HK, Nastaran S.Detection of Pseudomonas aeruginosa by a triplex polymerase chain reaction assay based on lasI/R and gyrB genes. J Infect Public Health. 2015 July ; 8(4):314-322 .

8. Anuj SN, Whiley DM, Kidd TJ, Bell SC, Wainwright CE, Nissen MD et.al. Identification of Pseudomonas aeruginosa by a duplex real-time polymerase chain reaction assay targeting he ecfX and the $g y r B$ genes. Diagn Microbiol Infect Dis. 2009; 63:127131.

9.Cotar AI, Chifiriuc MC, Banu O, Lazar V. Molecular characterization of virulence patterns in Pseudomonas aeruginosa strains isolated from respiratory and wound samples. Biointerface Res Appl Chem. 2013;3:551-558.

10. Sabharwal N, Dhall S, Chhibber S, Harjai K. Molecular detection of virulence genes as markers in Pseudomonas aeruginosa isolated from urinary tract infections. Int. J. Mol. Epidemiol. Genet, 2014; 5(3): 125-13.

11. Banerjee S, Batabyal K, Joardar SN, Isore DP, Dey S, Samanta TK et.al. Detection and characterization of pathogenic Pseudomonas aeruginosa from bovine subclinical mastitis in West Bengal, India. Vet World.2017. July .10 (4):738-742.

12.Al-Daraghi WA, Abdullah ZH. Detection of Exotoxin A gene in Pseudomonas aeruginosa from Clinical and Environmental samples.JNUS, 2013; 16 (2):167172.

13. Marta M. Philipp W. Pseudomonas Exotoxin A: optimized by evolution for effective killing. Frontiers in Microbiology, 2015 September.

14.McCulloch E, Lucas C, Ramage G, Williams C. Improved early diagnosis of Pseudomonas aeruginosa by real-time PCR to prevent chronic colonisation in a paediatric cystic fibrosis population. J Cyst Fibros. 2011; 2:21-24.
15. Hassan KI, Abdullah SA, Hawram KM. PCR ribotyping for determining the diversity of some clinical Pseudomonas aeruginosa. J of AlNahrain. Univ. Sci.2014; 17 (2):159-164.

16.Bradbury RS, Roddam LF, Merritt A, Reid DW, Champion AC. Virulence gene distribution in clinical, nosocomial and environmental isolates of Pseudomonas aeruginosa. J Med Microbiol. 2010; 59:881-890.

17. MacFaddin JF. Biochemical Tests for Identification of Medical Bacteria. 2nd ed., Waverly Press, Inc., Baltimor, USA. 2000; P. 64-67.

18. Oliveira CF, Paim TG, Reiter KC, Rieger A, D'azevedo pa. Evaluation of four different DNA extraction methods in coagulase-negative Staphylococci clinical isolates. Med. Trop. Sao Paulo. 2014 January . 56(1):29-33.

19. Loveday HP, Wilson JA, Kerr K , Pitchers R , Walker JT, Browne J. Association between healthcare water systems and Pseudomonas aeruginosa infections: a rapid systematic review. J. Hosp. Infect. 2014; 86:7-15.

20. Brooks E, Melnick J L, Adelberg E A. Medical Microbiology. 24th PP.189-201. McGraw - Hill. Nei M, Kumar S .2000; U.S.A: Oxford University Press.

21.Abro SH,Wagan R,Tunio M T, Kamboh AA, Munir M. Biochemical Activities of Bacterial Species Isolated from the Frozen Semen of Cattle. J Agri Social Sci. 2009; 5: 109-113.

22. Potron P, Poirel L, Nordmann L. Emerging broadspectrum resistance in Pseudomonas aeruginosa and Acinetobacter baumannii mechanisms and epidemiology. Int J Antimicrob Agents.2015;45:568585.

23. Whiley DM, Lambert SB, Bialasiewicz S. Falsenegative results in nucleic acid amplification tests: do we need to routinely use two genetic targets in all assays to overcome problems caused by sequence variation. Crit Rev Microbiol. 2008 ; 34:71-76.

24.Song KP, Chan TK, Ji Z L, Wong SW.Rapid identification of Pseudomonas aeruginosa from ocular isolates by PCR using exotoxin A-specific primers. Mol Cell Probes. 2000; 14: 199-204.

25. Salman M, Ali A, Haquesalman A. A novel multiplex PCR for detection of Pseudomonas aeruginosa: A major cause of wound infections. Pak J Med Sci. 2013; 29(4): 957-961.

26. Neamah, AA. Molecular Detection of virulence factor genes in pseudomonas aeruginosa isolated from human and animals in Diwaniya province. Kufa J vet. Sci. . 2017; 8 (1):218-230.

27. Thamir E, Al-Jubori S. Genetic detection of some virulence genes in Pseudomonase aeruginosa isolated from cystic fibrosis and no-cystic fibrosis patients in Iraq. J.Genet. Environ. Resour.. 2014, 2(3):380-387.

28. AL-Salihi SS, Hasan AY. Detection of some virulence factors in Pseudomonas aeruginosa associated with diarrhea in Kirkuk City. KUJSS, 2015, March; 10(1):78-89.

29. Woods D E, Iglewski B H. Toxins of Pseudomonas aeruginosa: new perspectives. Rev. Infect. Dis. 1983; 5:714-722. 
30 .Motoshima M, Yanagihara K, Fukushima K, Matsuda J, Sugahara K, Hirakata Y et.al. Rapid and accurate detection of Pseudomonas aeruginosa by real-time polymerase chain reaction with melting curve analysis targeting gyrB gene. Diagn Microbiol Infect Dis. 2007;58:53-58.

31. Khan AA, Cerniglia CE. Detection of Pseudomonas aeruginosa from clinical and environmental samples by amplification of the exotoxin A gene using PCR. Appl. Environ. Microbiol.1994; 60: 3739-3745.

32. Melendez JH, Frankel YM, An AT, Williams L, Price, LB, Wang NYet.al .Real-time PCR assays compared to culture based approaches for identification of aerobic bacteria in chronic wounds. Clin Microbiol Infect. 2010; 16: 46-54.

\section{الكثف عن السلالات المرضية لبكتريا Pseudomonas aeruginosa باستهذاف جيني الضراوة ETA و gyrB}

\author{
سامان رفيق عبدالله
}

\author{
خلود ابر اهيم حسن 1 \\ 1قسم علوم الاغذية وتغذيه الانسان، كلية الزر اعة، جامعه السليمانية

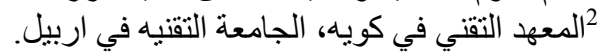

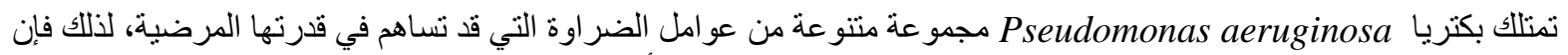

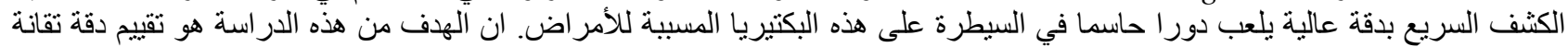
P. aeruginosa. تفاعل البلمرة المنسلسل (PCR) و

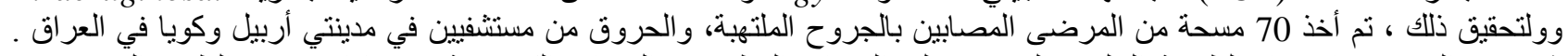

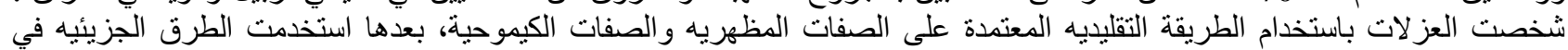

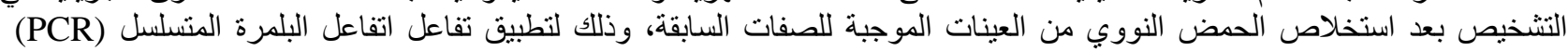

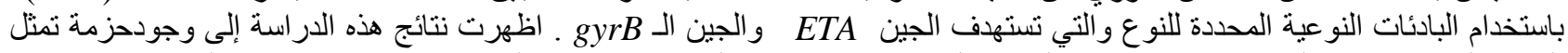

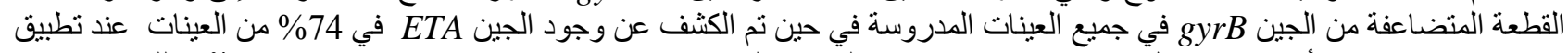

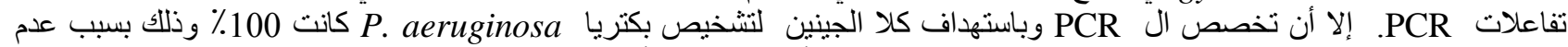

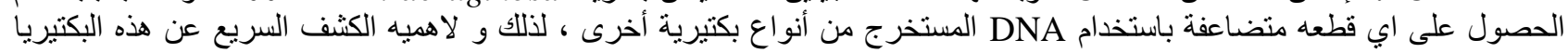

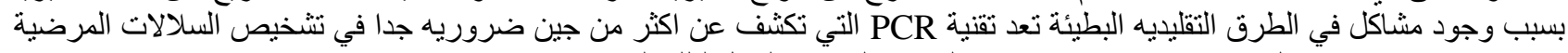
من P. aeruginosa و والتي تساهم بدور ها في تحديد المضاد البكتري الفعال لتلكاك البكتريا. الكلمات المفتاحية : كثف، شخيص، PCR،ETA, gyrB ، Pseudomonas aeruginosa 